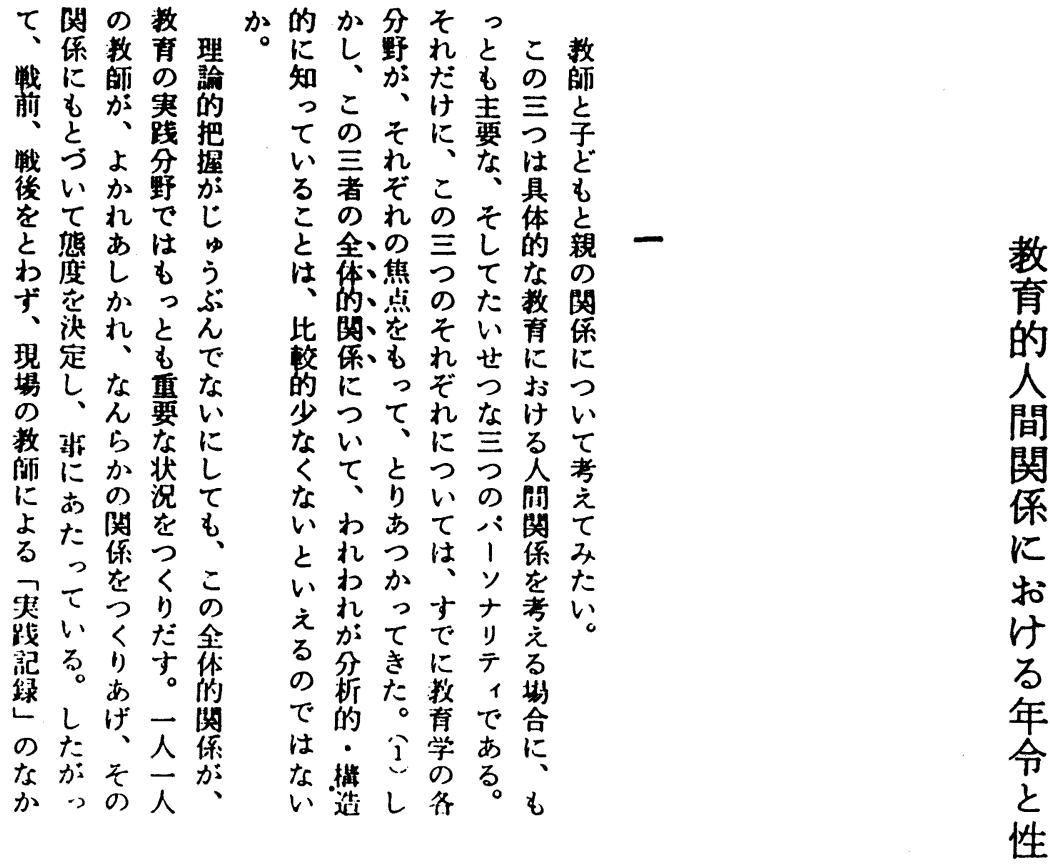

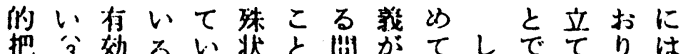

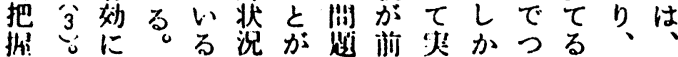
を，航し綕性多を热悠しく攷あこ

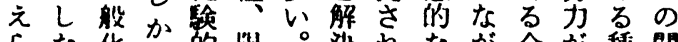
$5 た$ 化的显。狄れなが全が種闺

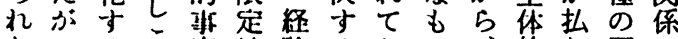

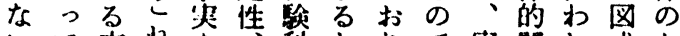
いて方机老科たりで具明机式と

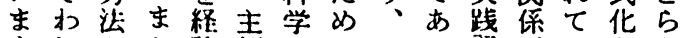
まれとた得毁とのまる記がいさえ

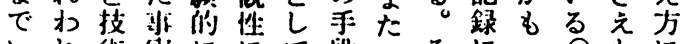

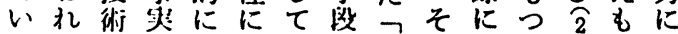

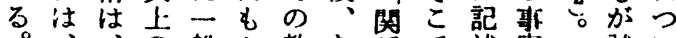
高般か教な係で述实陚い 化ま间化か势い边さ上こみて 然た漹与社しは特れののらの とじとるら会はこ蛋て重これす しいし必ず学背の翗い要とれ、 てうて要、时等状況る性は具れ こぶ、がこ、它況に阙を、体た のん契あの夹しにつ係反教的洞

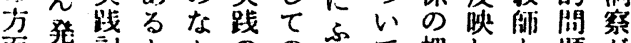

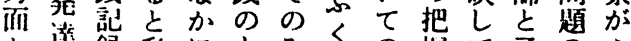

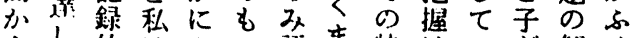

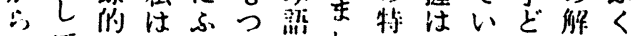

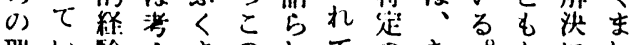

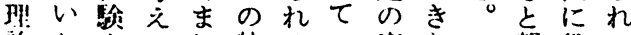
原 


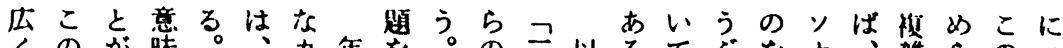

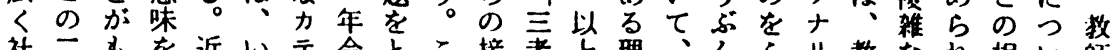

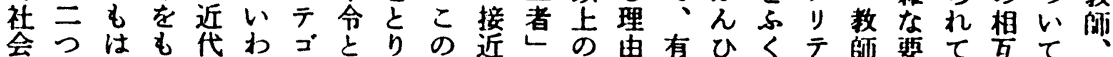

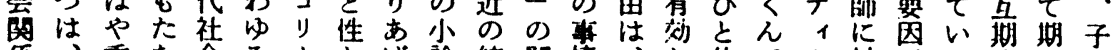

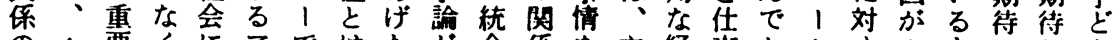

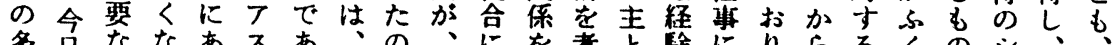

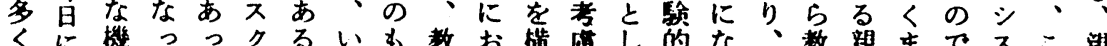

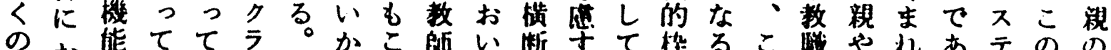

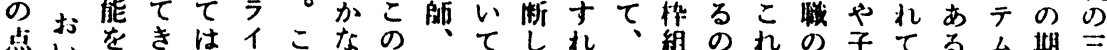

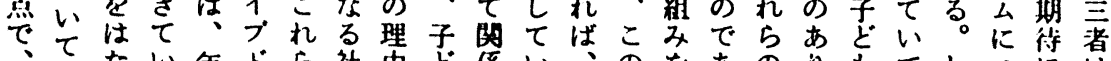

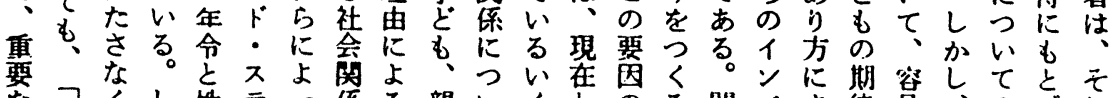

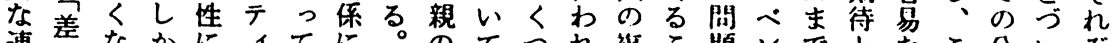

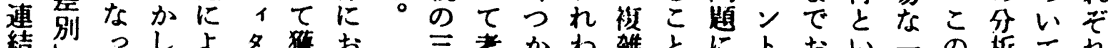

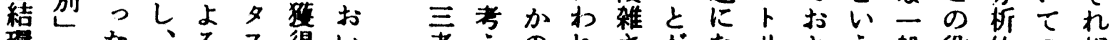

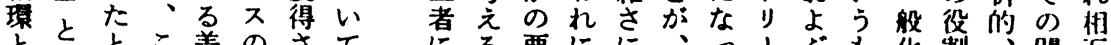

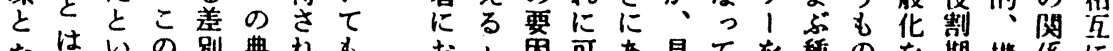

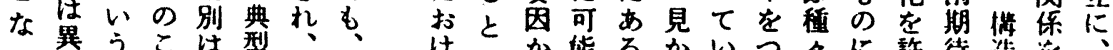

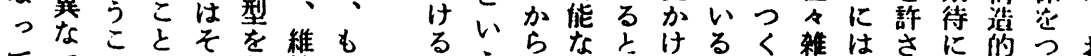

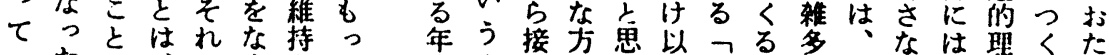

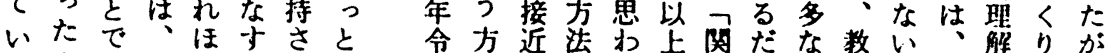

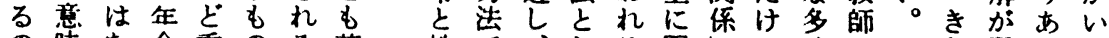
の味な令重のる基性で、しる困しでくのたお現げの

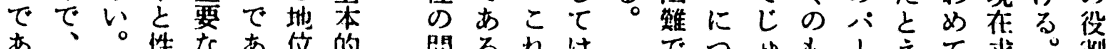

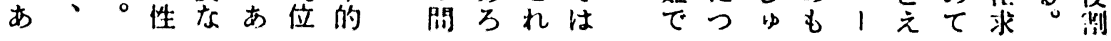

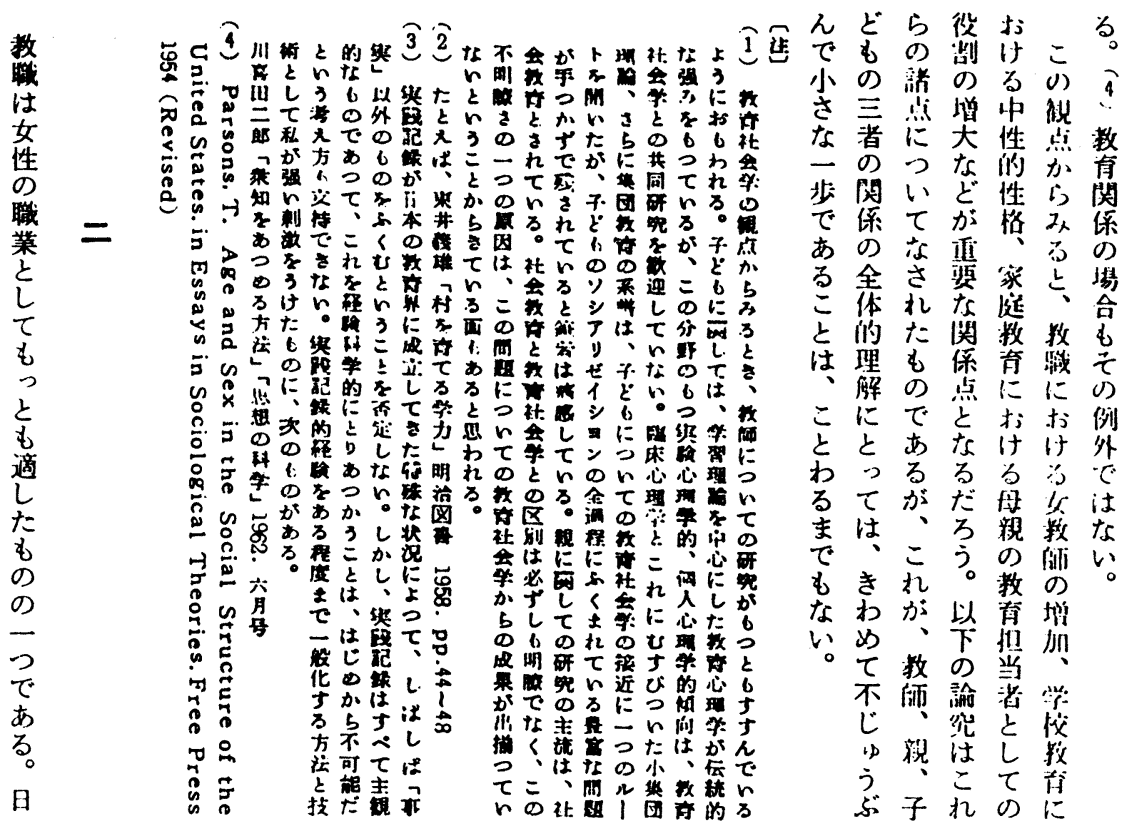


苏 1 敦

\begin{tabular}{|c|c|c|c|c|}
\hline 性别 & 地位别学校只 & 小学校 & 中学核 & 矿等学佼 \\
\hline & 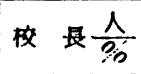 & $\frac{22,046}{6.3}$ & $\frac{10,259}{4.4}$ & $\frac{3,252}{2.4}$ \\
\hline 男 & 教 諭 穴 & 47.6 & 73.0 & 80.8 \\
\hline & 小計 \% & $53.9 \ldots$ & 77.4 & 83.2 \\
\hline & 校 报 $\frac{1}{y^{\prime}}$ & $\frac{96}{0.03} \approx$ & $\frac{17}{0.007}$ & $\frac{144}{0.1}$ \\
\hline 女 & 数 袘 兑 & 46.1 & 22.6 & 16.7 \\
\hline & 小㖕吕 & $46.1 \ldots$ & 22.6 & 16.8 \\
\hline it & $\frac{1}{\%}$ & $\frac{348,876}{100}$ & $\frac{231,593}{100}$ & $\frac{134,378}{100}$ \\
\hline
\end{tabular}

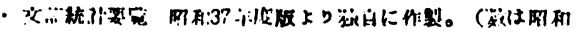
$35: 5 \pi 1$ ii 猎保)

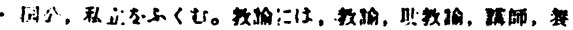

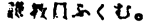

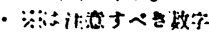

い全のは增ら新女清 は床第洏教加少し性戦 人の1向倳はの<の争 為四表注に教波開職以

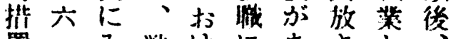
固・子戦けにあるを が一る時るおうれさ打 と\%上中女けたた机本 らにうの性るに、ての 机陸に男の女世有き女 なし、性地性よ望た性 いて現不位の、な \& が かお在足を比女瀜の社 きり月をい率教業を会 り、本契くの師の強に ここの機ぶ增の一化進 近の小とん加数つす出 い数学:し高とはでるす 将字校て めな着あこる 来はに大るり実っと乎 にと拟に、にた劣か さくけにとさ增。のか らべる強にら加そぞり につ女め役にしのいは 㙋の教门立比、絬て

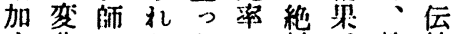
す化のたたの対、教統 るあ数。增数、い職的 可るはこ加のく肪に

こルきラ园をて1能 れコでンに机打了性 をなあ夕゙打教りにメが みどろにい皈、属りあ てのうかてで今すかる

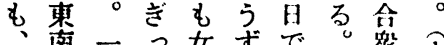
日市方七教的はこ园主 本ジ、四師る約のに の丁比 $\bigcirc$ ま 七同打

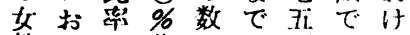
教よの代はに\%は吕 闻ひ低に男な、、竞 の中いあ教っ小一わ 增近国乃细て学入的 加東とが壳い校七て

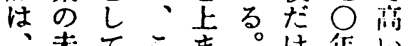
、未てこ㚣。け作い 先间は机おしに代女 進発、はつかつに教 工籍夕まてしいす的 業国イた打他てでの 蓝に、别りのいに比 国子工㑑、主え六将 にらジにド要ば○は 接机ブ考イな、\%特 近るト㦄ツ西九に界

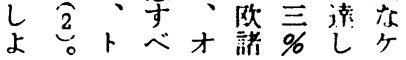

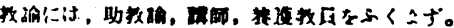

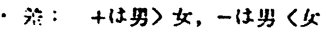

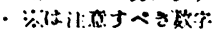




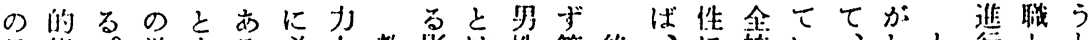

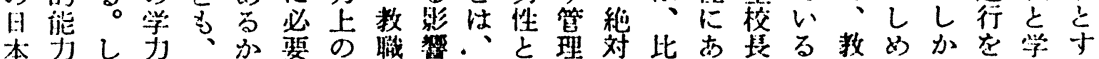

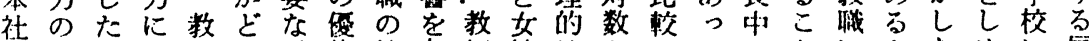

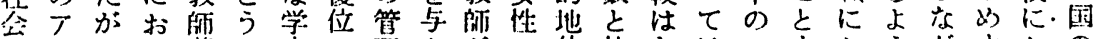

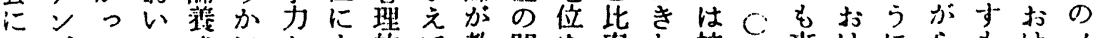

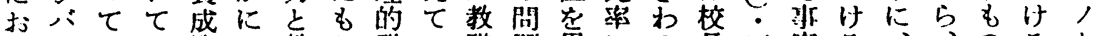

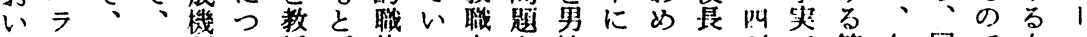

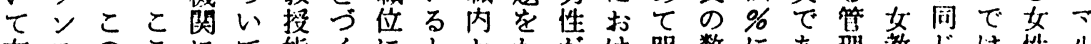
有スのこにて能くにと打方け明数にあ理孜じは性儿

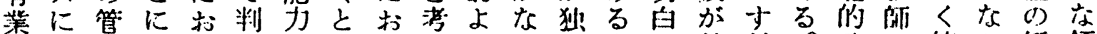

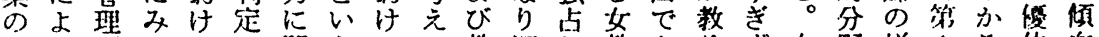

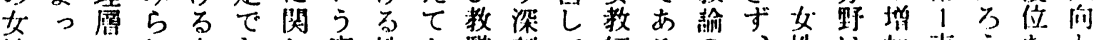

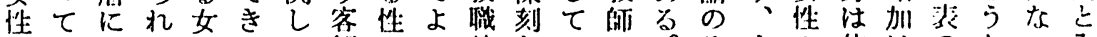

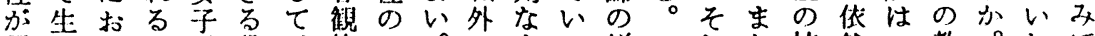

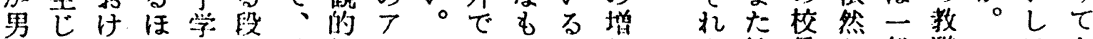

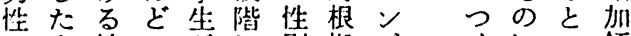
にも性の方に别扰公くにい倾 比のの差男はにはラるえしう闬

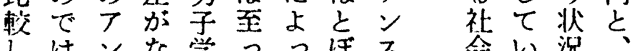

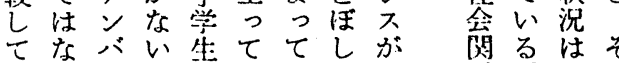

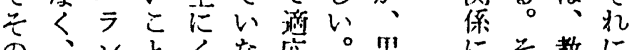

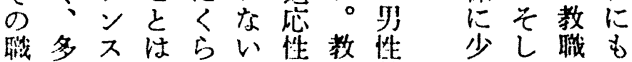
洋分は朋べ。の職教なてにか 活、白て少相の町少こ尔か 政客で、な異遂の

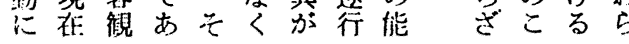

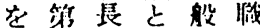
う 2 はし 教 $の$

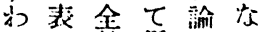
志に教够市 わ拀䝿性しで

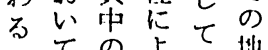
のてのよて 㙐

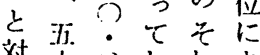
対 $-1 \therefore$ ᄂ 机占 比代 : ゆでる 古 $0 \%$ 少市分 はよ 女.

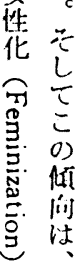
の) 数

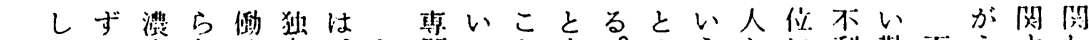

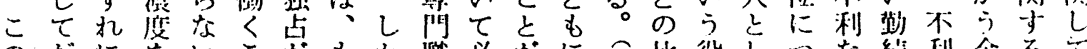

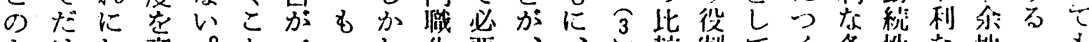

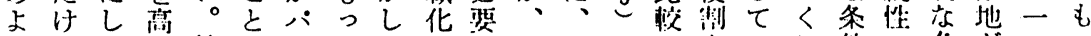

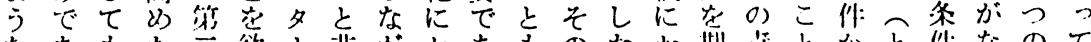

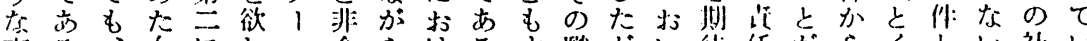

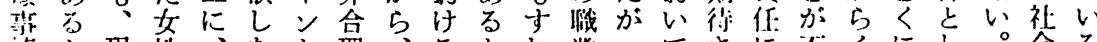
情亡現性なと理、ると机㳻ってさに不くにし。会る

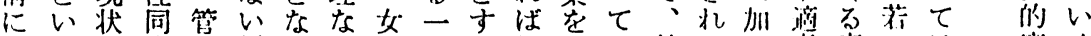

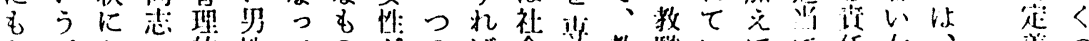

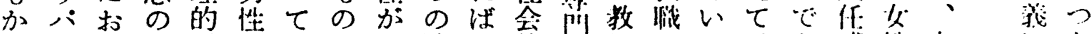

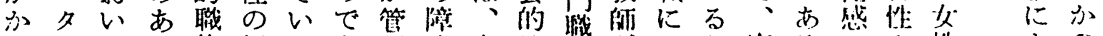

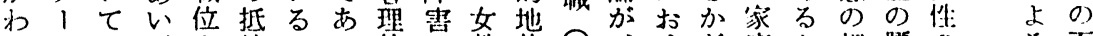

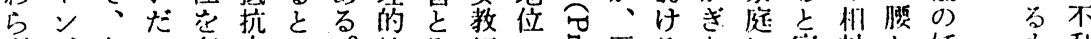

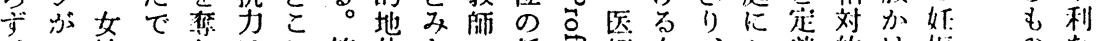

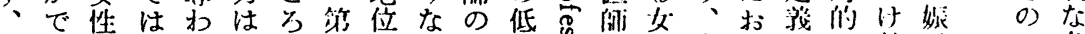

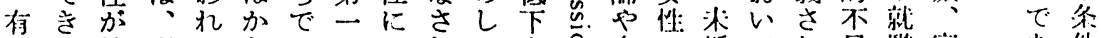

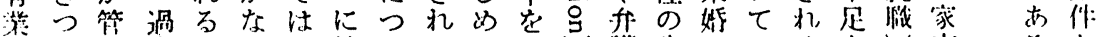

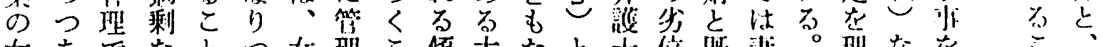

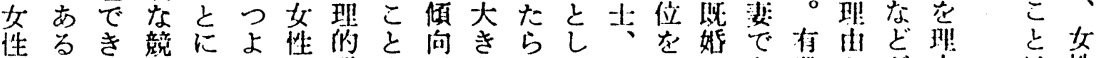

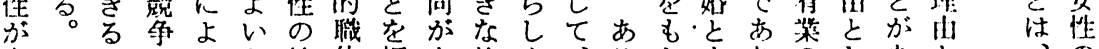

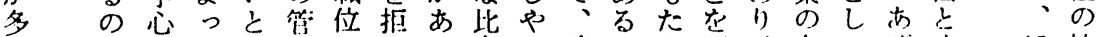

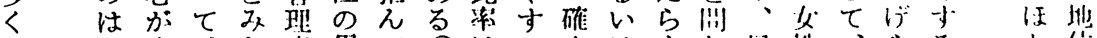

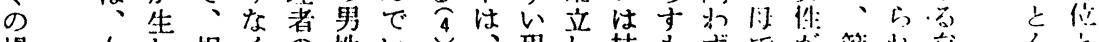

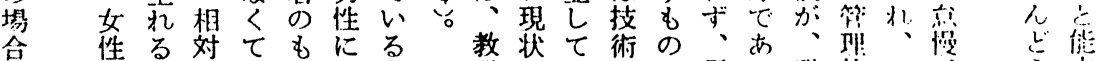

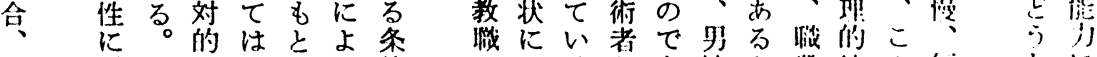

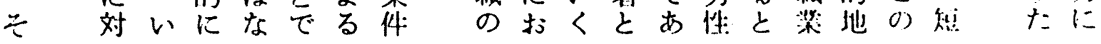




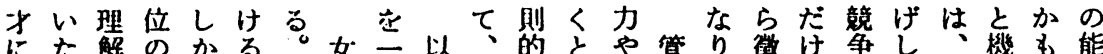
にた解のかる。女二以、的とや管り徽け争し機も能 おいさ男し主こ性つ上教基を教理あ䒚の闺い女会し力

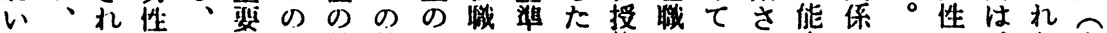

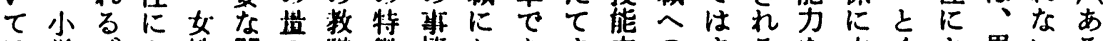

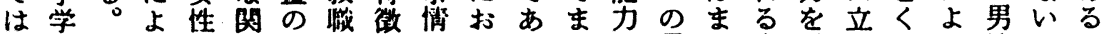

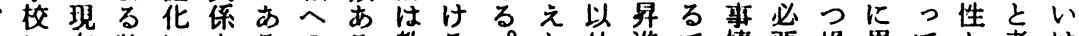
校に在独にをるのる教る。と外萑て倩要场男てと考は

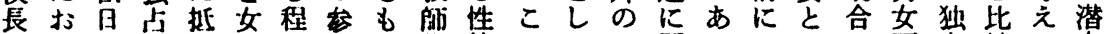

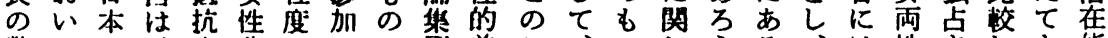

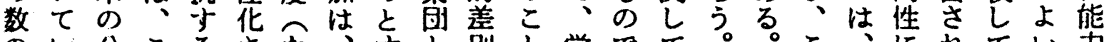

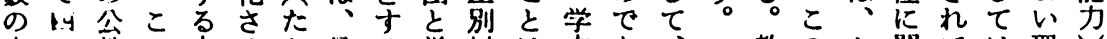

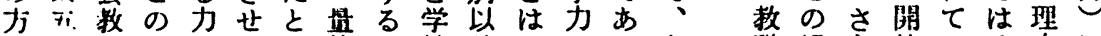

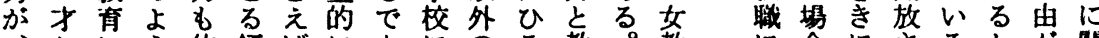
、かにう化㑯ばにあにのる教。教に合にさるかが関 平ら打な然向半增乃何が授し師市おにの樴にあし 教急い抵とを数加うけをえ能がか けはだて種制るて

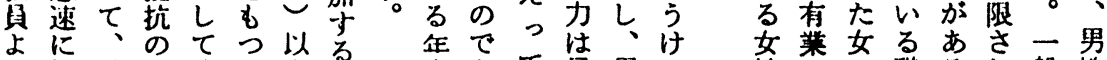

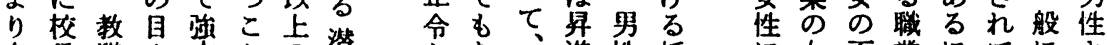
多畏職立方との替とな、進性抵に女不莱にてによ

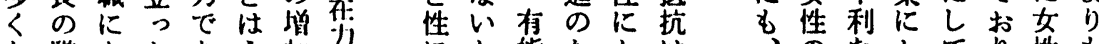

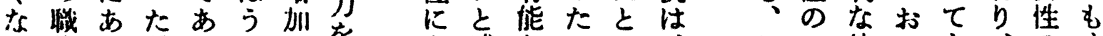

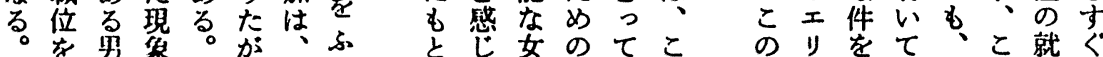

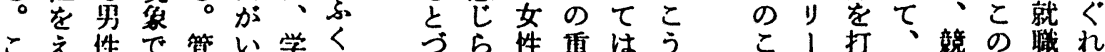

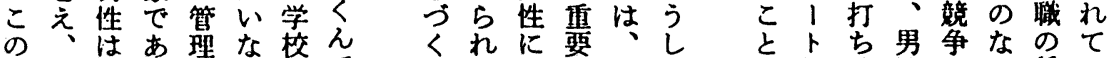

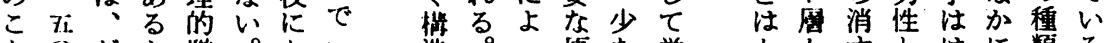
上つだと哦。おい造。っ原な学かか方とは類る

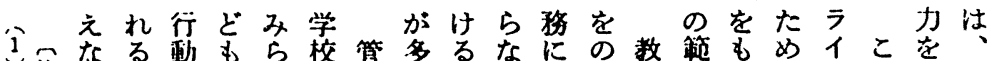

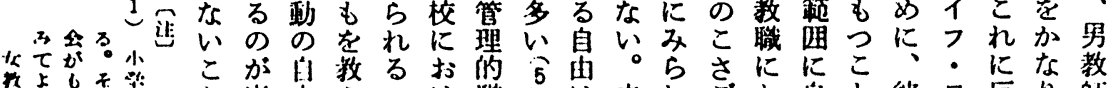

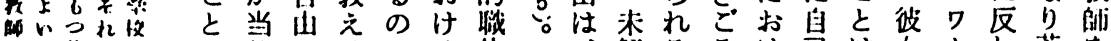

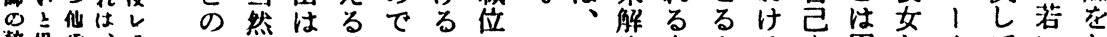

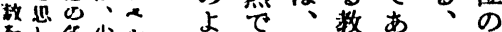

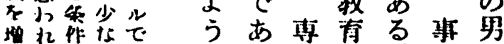

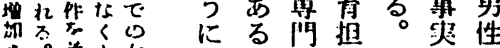

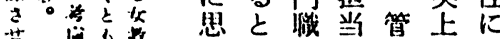

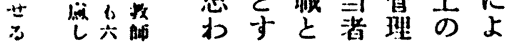

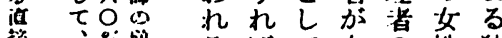

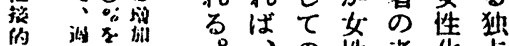

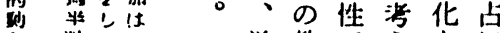

* 然 i

は 行方

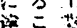
学教でえをに こ決官をるを困たクていし のの僚得官限難ちと女とて

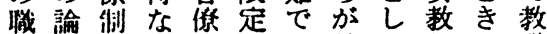
業争とW制しあ教て師か䁢 に点の值はがり職行は品 おを比向飞ち、にな、期引 け多教をのでクつうそ待イ るくにも米あラいにのさフ 判のおつ端るスては数せ! 断こいて部。? の多のるワ 校瞕あが生的 教のりい文か

$\overline{0} \quad 15 t^{2}$

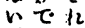
ix 2 t 状 位合 增 $\mathrm{CA}$ of th 然 lis $\sim$ H: $\tau$ $0 \leqslant 0$ it 1 船 j丁 $\tau$ 淌 *) c () li lii) 二留七 声部、かたか の山しな子小 事のかる一ら

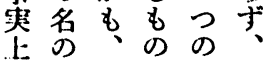
のむ彷で㘳女 女之灭あ盤教 性に品招を師 は詐判酟の增 避容喇接点加 行していに

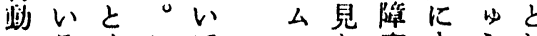
のるくこて ・と吾むうし 自とにの、市を索京て

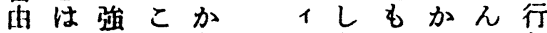

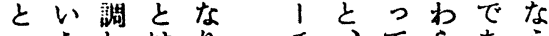
二え致、なは

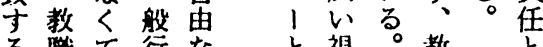
る 壦て 行な こには政 領 けさと子にか

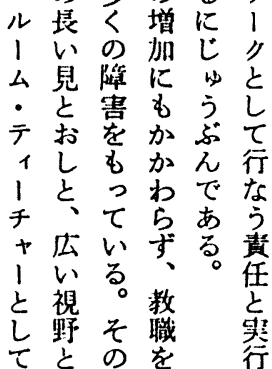


机は性等一当て年男售华小

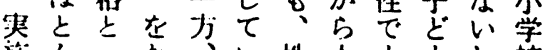

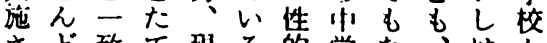
さど致テ現る的学な、はか れ無于宝在。な校くす女ら る抵るえの発安、く性中 こ抗ばと日龍で好な化学 とにかし本のに性くの校三 にっりての点つでと傾に よ少でお公梁いも向问か ななり教毛てな小党け $\tau<く 、$ 势 学とこ校とには交校つの 文教のこお 化南 $\vec{c}$ 衣 の対致は、は 性に条子

的開件 它珄

性しと格しに

はてて方莎

さ约、けて

に帮等蛙男

強施数性女

化さ青的平
るば珄中心瓜

㧹学字

男の考年 の

の子えま間

子茫てで艺

を男よ壮它

ま子。生学

る壱さ体的玟

時位にに化

期に、み、は

に打高て 功

相い学、珄

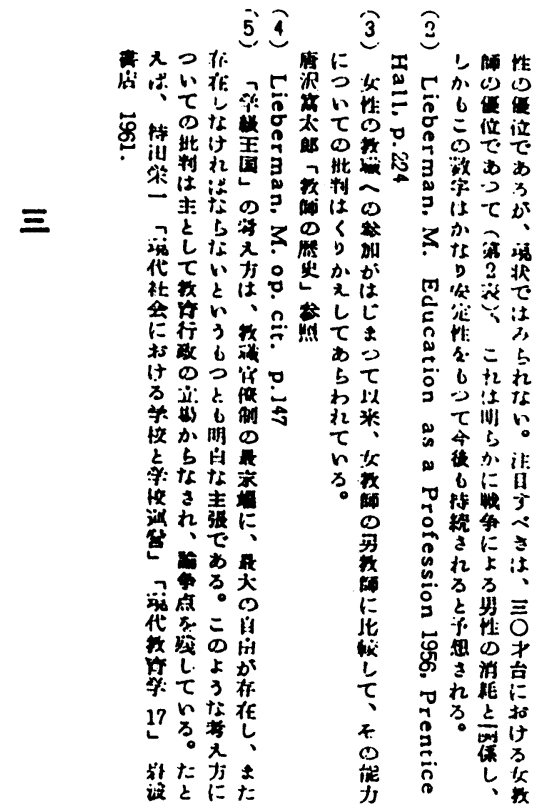

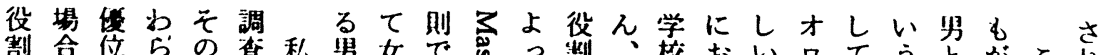

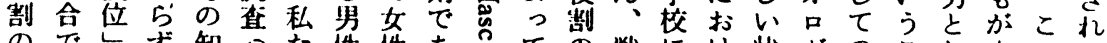

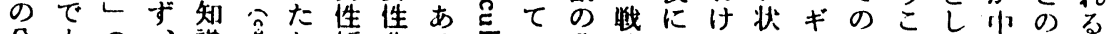

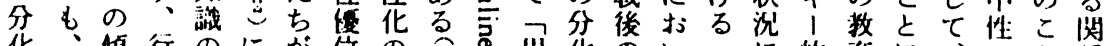

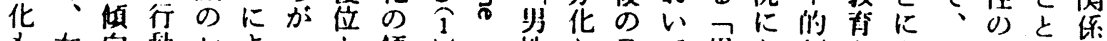

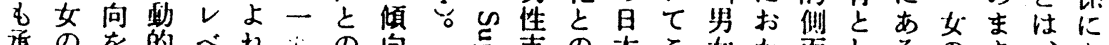

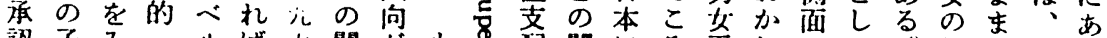

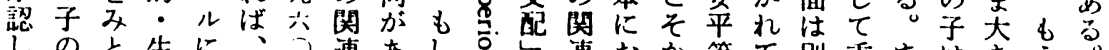

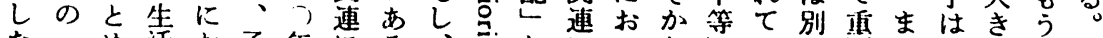

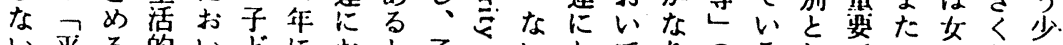
以平る的いどに拉と子かい扰てりのるしでことなし ほ等方レてす行いすをがしいむ费たとてあのしるく

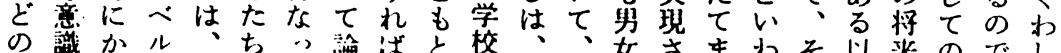

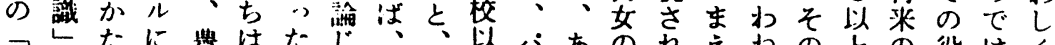

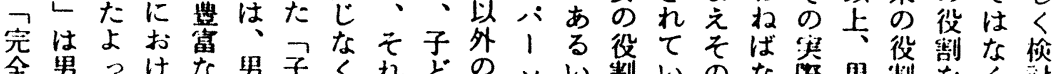

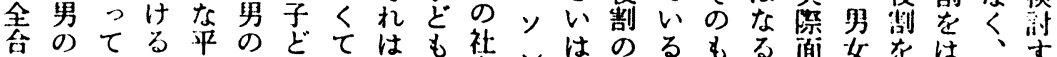

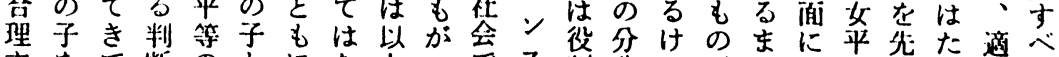

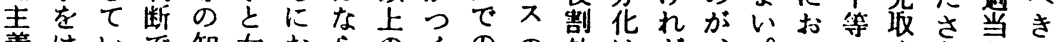

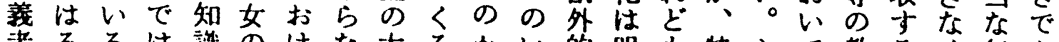
者るるは傤のけな大るかい的明毛特さて教るく年あ

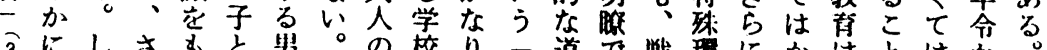

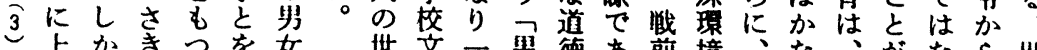

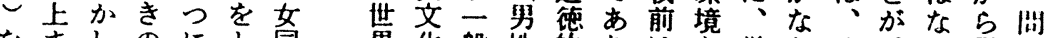
をましのにと同界花般性的りはと学りそて、ら罗题

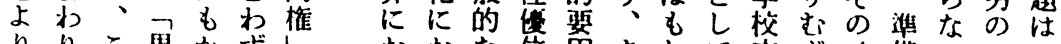

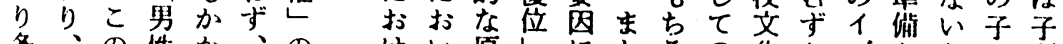
多、の性か、のけい原ににたろの化かデととは亡 


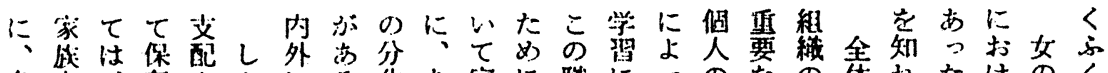

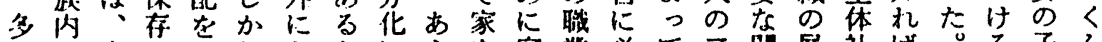

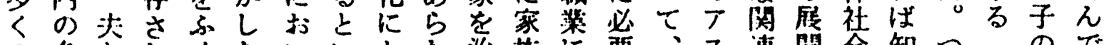

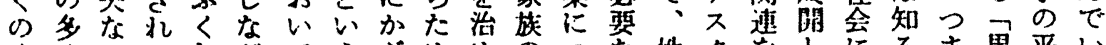

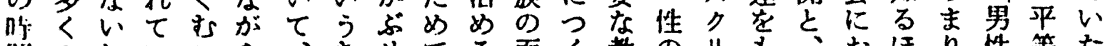

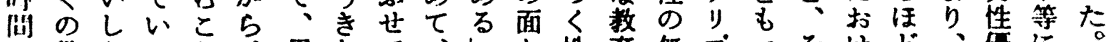

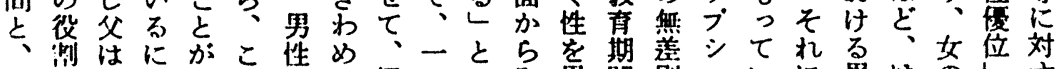
紤を文でののて经つい及男間別

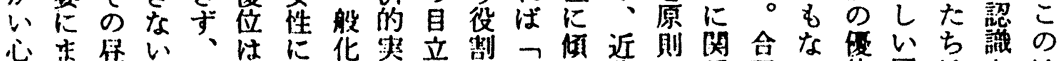

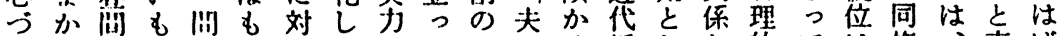
かせのの题は性たのた分はせ婚しな的ては権、芘げ いさ眮で状やる通あ特化外る姻てく職成意社县し

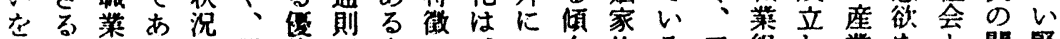

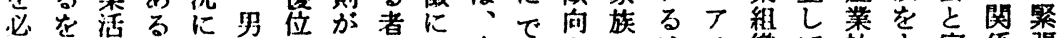

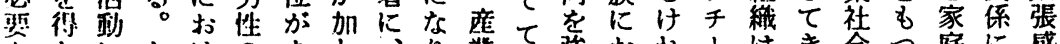

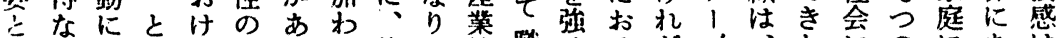

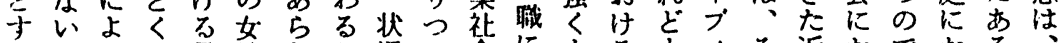

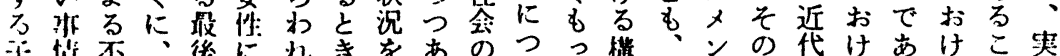

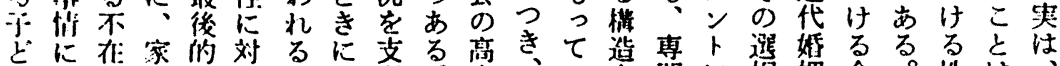

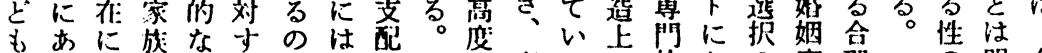

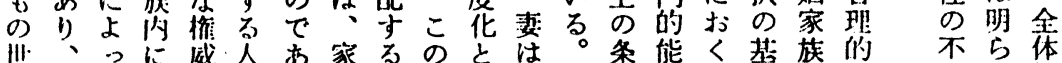

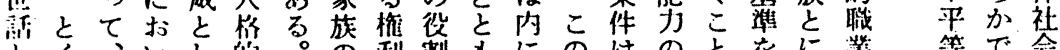

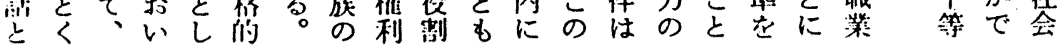

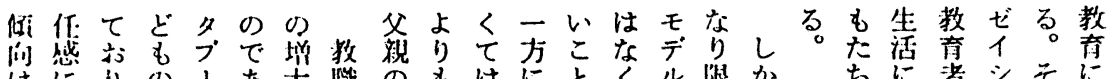

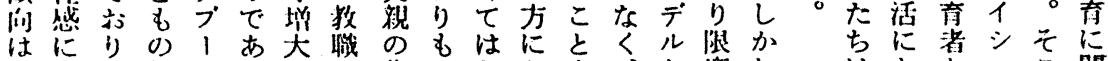

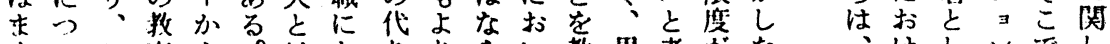

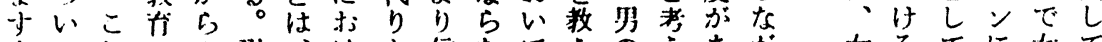

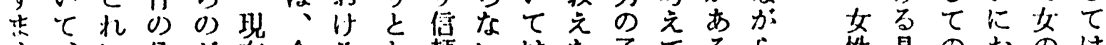

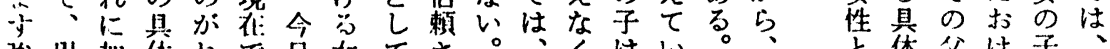

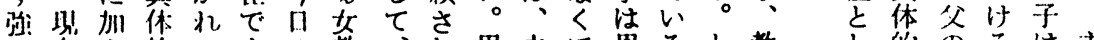

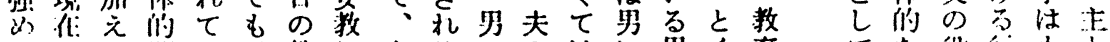

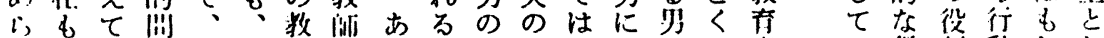

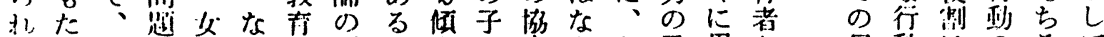

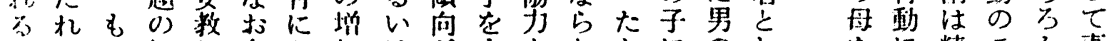

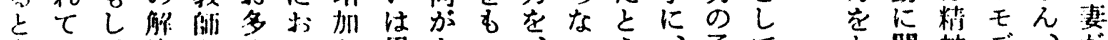

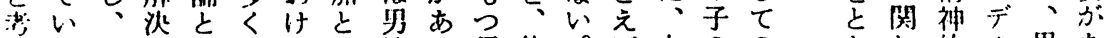

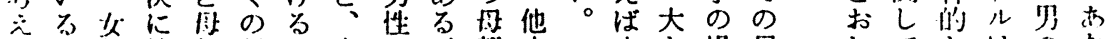

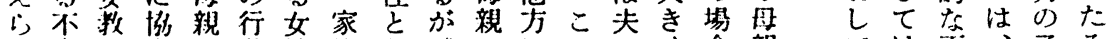

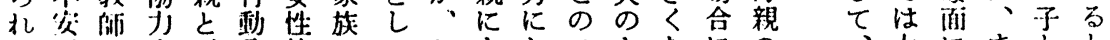

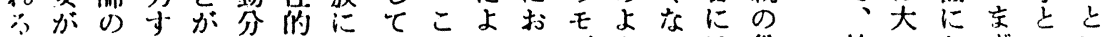

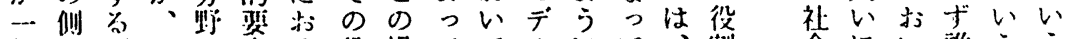

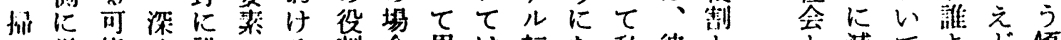

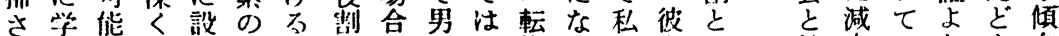

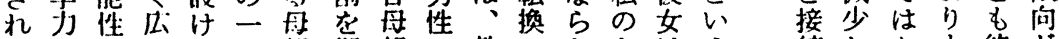

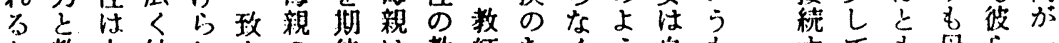

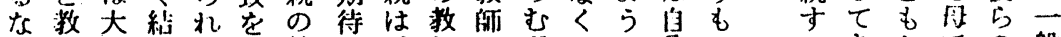
ら授きびてす教し、阿にずてに分ののうかでの般

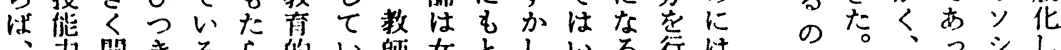

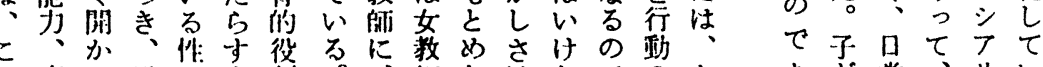

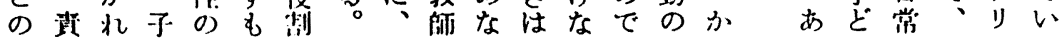


ら性い易況わなはいの公直功会やいおにのな原

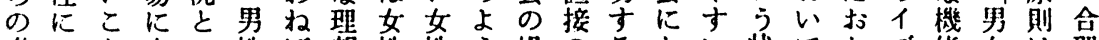
唯上と女の性ば想性性う场のるおい状てかデ能女时 一るは性類のな像化のな面利見け㑯涗も机才に平、们 の管な化似教ら苍理利で害込る向は、て等多倳

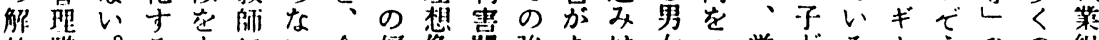

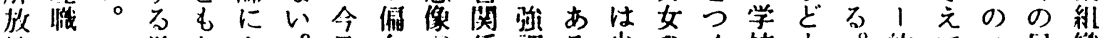

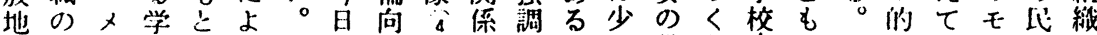
区独イ校めるをををしをはたな役り文を子则いラ主に で占口教る管と救には必けい制た化龍上゙面るル主対

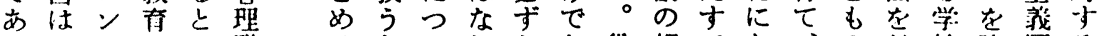
る、・のい職るきいれしな役相で拉のしし校㧧国る

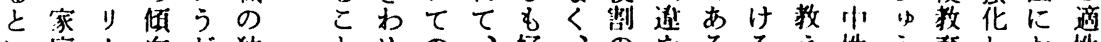

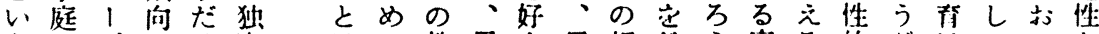
うとパにけ占はて教男ま日相しう䒠る们ぶはていか

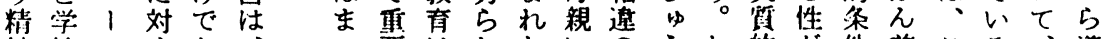

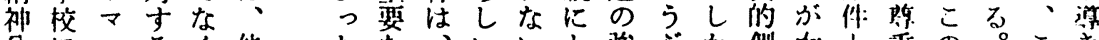

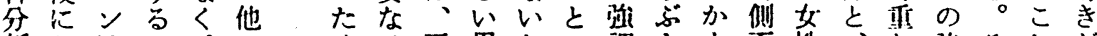

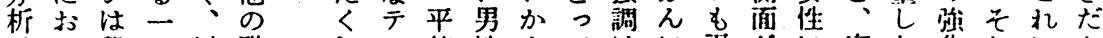

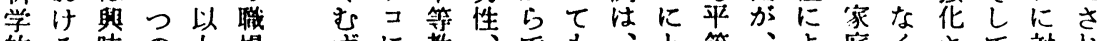

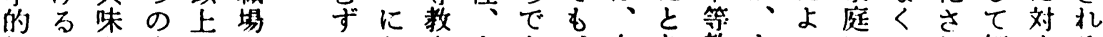

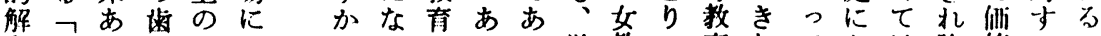

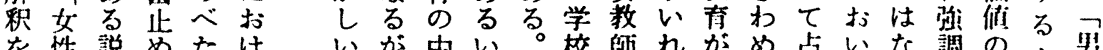

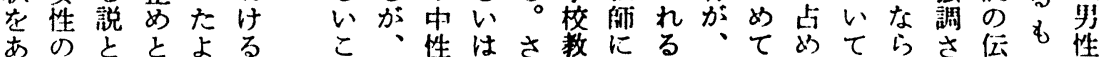

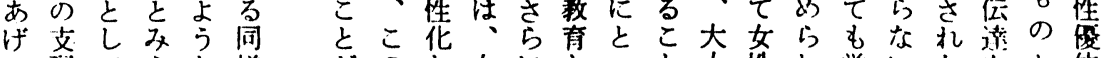

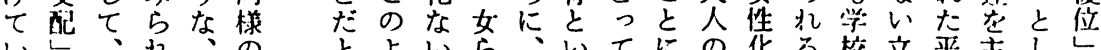

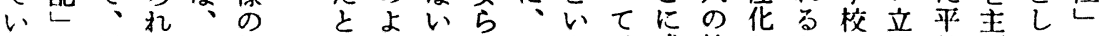
るか男な俩状いうししこう成社しとに場等变ての

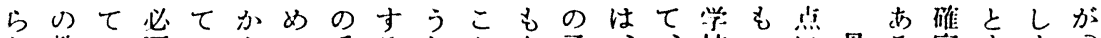

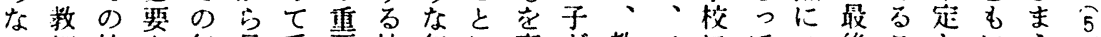

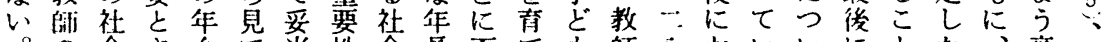

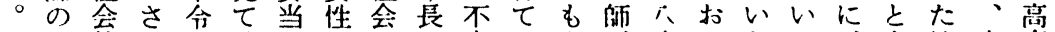

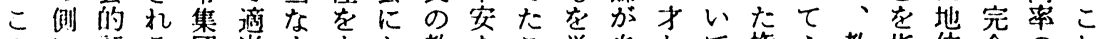

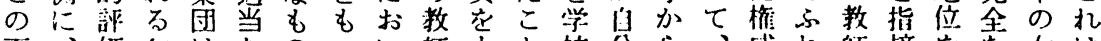

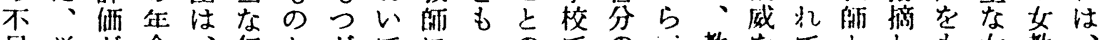
足菏が令、作とがてにつのでの

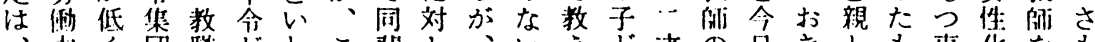

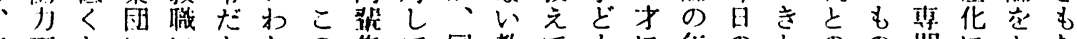
作不打ににとなの集て同教てもに作のたのの䢹に亦な

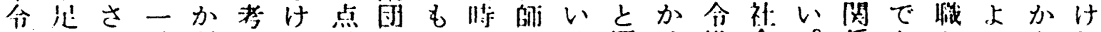

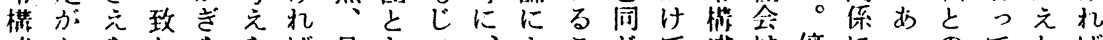

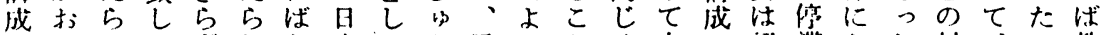

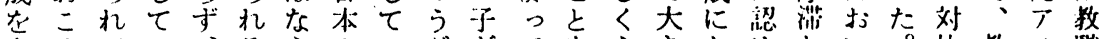

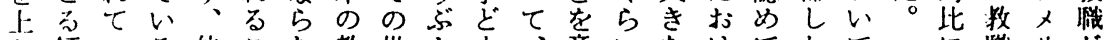

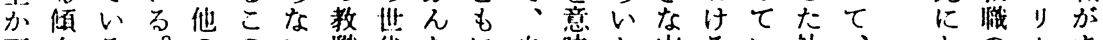
下间る。ののい哦代なに味机るい社、打の力ま

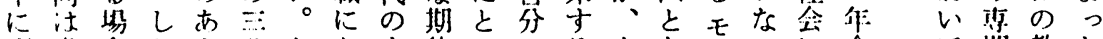

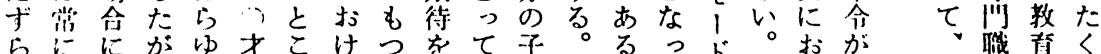

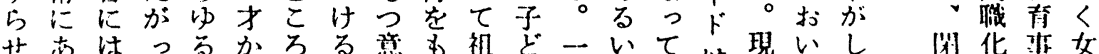

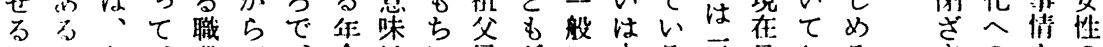

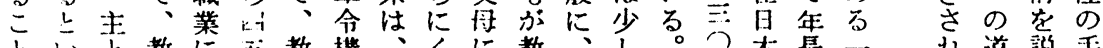

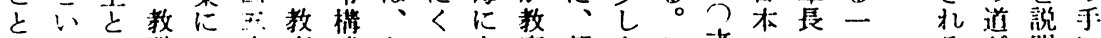

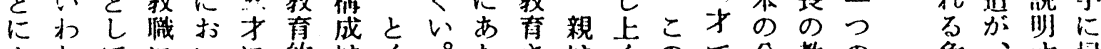

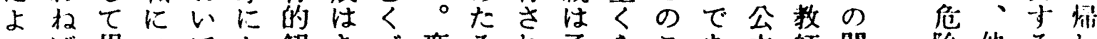

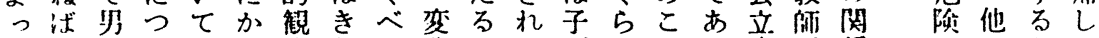

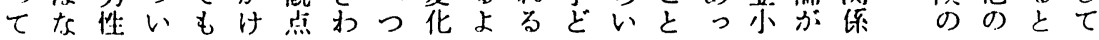




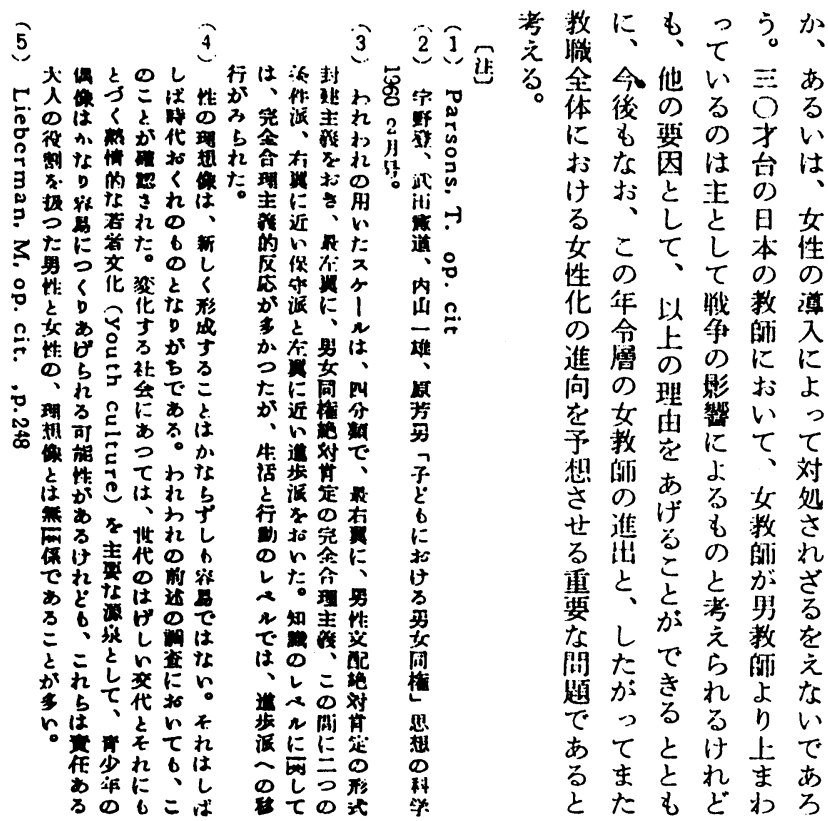


of the organization of teachers groups and the morale of the teachers' groups to a great extent. In this resicet it can be stated that the status of the organization of the teachers groups is closely related to the morale in education.

\section{Age and Sex in the Educational Relation}

\section{Yoshio Hara \\ (Tokyo Institute of Technology)}

The teacher, the child and the parent are the three main personalities in educational research. Each of them has been studied in different branches of educational sciences with particular emphasis on their own method, but many things are still unknown with regard to the total structure of the reciprocal relations among these three interacting personalities.

This paper deals with age and sex as a connecting link of the relationship in which an emphasis is put on a tendency of feminization of the teaching profession, sex neutrality in school culture and the increasing responsibility of child rearing in the family.

The remarkable increase of Japanese female teachers reached $46 \%$ in 1961, but administrative positions are almost occupied by male teachers. (the ratio of female principals in the elementary schools are only $0.13 \%)$ Consequently the equality principle is particularly emphasized in the teaching profession. The increasing feminization in the teaching profession in Japan is stimulated by (1) the real and potential increase of female teachers, (2) female teachers' strong desire for equality in treatment, (3) classroom teachers' autonomy in school administration which has been strengthened after world warII.

Combined with sex neutrality in children, the equality principle tends to create girl's superiority in school culture because girls are more eager in "emanisipation drive" than boys.

One other factor of the feminization in education is the woman's role in the conjugal family. The kinship system which has been prevalent uncler the development of industrialization is the nuclear family consisting of the limited menbers of husband, wife and their children. In this simple family organization the responsibility of child rearing is, as a rule, placed on the house wife, the mother. She becomes a significant "role model" for boys as well as girls. Thus children are raised chiefly by women at home and in the school.

In spite of the sex differentiation by the sexes and the tendency of masculire superiority in the total society, education in Japan is 
inclined to be dominated by the tendency of feminization and will be more in the future.

\section{Human Relations in Industry \\ Problems related to Guidance of Trainees at the Training Institute for Technicians attached to " $A$ " Company \\ Tomiz̄ Yamaguchi}

(Tokyo Institute of Technoogy)

Education-in-industry for young workers has become increasingly imfortant, but there remain many unsolved froblems. In this paper an attempt has been made to investigate the consciousness of young workers in a big industry as to their caily life in the factory, and to clarify some of the crucial points in terms of guidance of the trainees. For this purpose, the trainees of the second and the third year classes have been asked to answer the questionnaire as well as interviewed.

The following points have been made clear:

(1) There is a deep discrepancy between the image of their work before the workers came to the factory and after they entered. In a word, most of the trainees had their expectation betrayed after they entered the factory. This will give important suggestions to the teachers of junior high schools as well as to the trainers of the training institute with regard to the guidanee of their pupils.

(2) A change is taking place with regard to the consciousness of the trainees and their human relations as they become upperclassmen.

(3) There are some inconsistencies on the part of the trainers in industry. For instance, the trainers cleverly distinguish the educational principles at school from those in industry. This will not only lead to unnecessary confusion and criticism on the part of the trainees but also remain as an unsolved problem on the part of the trainers.

(4) In order to uplift the morale of the trainees it is necessary to reform institutional aspect and to make fundamental improvement of the order and working conditions in the factory. To achieve this purpose, it is most important to establish the status and the rights of the trainers in industry. 